\section{Work of the Falmouth Observatory}

THE Report of the Falmouth Observatory Committee to the Royal Cornwall Polytechnic Society and the Falmouth Town Council for 1935 is a small booklet which includes meteorological notes and tables for that year. The Observatory possesses records for various meteorological elements that extend back so far as 1871, from which sixty-five year averages have been computed. These are included in the publication, and are used as a basis for comparison of each of the past five years with the sixty-five years in question. It may be noted that 1935 completes one of the lustra recommended as a basis for such comparisons by the International Meteorological Congress of 1887. The rainfall figures show that only one of these five years (1931) was wetter than the average, and by only a small margin, and those for atmospheric pressure show that 1935 was the only one that had not a substantial excess of pressure. Temperature was above the average in each year; the mean for the lustrum was $51 \cdot 9^{\circ}$, which is identical with the mean for the previous lustrum, this figure being $1 \cdot 2^{\circ}$ above the average. It is interesting to note that temperature at Falmouth has been above the normal for thirteen successive years. The outstanding event of the year 1935 was the snowstorm of May 17. The cold was very much less severe on that day at Fal. mouth than over most of the country, for temperature there did not fall below $35^{\circ}$ in the screen; but on May 14 there was an unusually late ground frost, and this caused very severe damage to crops in some parts of Cornwall. In the section dealing with sunshine, reference is made to the fact that, according to an Air Ministry Pamphlet (No. 69), in two respects Falmouth is the most favoured place in the British Isles in that it has the smallest number of sunless days and the highest number of days with sunshine of more than three, six, and nine hours' duration. Cornwall, in addition to considerable immunity from frost, escapes extremes of heat; at Falmouth the temperature has reached $80^{\circ}$ in only eight years out of the last sixty-five.

\section{Loan Collections for Museums}

Ir cannot be too widely known that there are available for local museums and art galleries small collections of objects of art and of scientific interest on loan from the British Museum and the Victoria and Albert Museum. The objects are accurately labelled, and each set is contained in "one museum case of the ordinary type". The collections cover a wide field of interest. For example, to mention a few, the Victoria and Albert Museum has forty-three sets illustrating Far Eastern pottery and porcelain, thirty-four sets of English pottery, porcelain and tiles, fifteen sets of English silver and Sheffield plate, twenty-seven sets of English and twenty-nine of European embroideries and woven fabrics, and six sets of musical instruments. On three months' loan from the same museum may be obtained collections of water-colours of the British school, Charles Keene's $P$ unch drawings, Japanese colour prints with the tools and materials used in the process. Somewhat similar collections are lent by the British Museum, including water colours by J. M. W. Turner, and additional sets illustrating typical Egyptian gods, and the handiwork of the Bronze and Stone Ages. Information about the conditions on which the loan collections are issued may be obtained from the directors of the museums mentioned.

\section{Corrosion of Iron and Steel}

The Joint Corrosion Committee of the Iron and Steel Institute and the British Iron and Steel Federation has so far presented three reports which contain a large amount of information. Although the work is at the present time in a very preliminary stage, particularly perhaps with regard to the effect of the protection provided by paint coatings, there is, in view of the extreme importance of the subject, every justification for presenting a short abstract of the results so far obtained. This has been done by Dr. W. H. Hatfield in "The Work of the Corrosion Committee", Special Report, No. 11. This summary, which is extremely well done, contains some pro. visional conclusions of considerable practical importance, and may be recommended most strongly to all who are concerned with the corrosion, or the protection from corrosion, of ordinary steel structures.

\section{Canada's Datum Level}

THE use of different datum planes in Canadian surveys has in the past led to some confusion. The first precise levels run in 1883 were linked to the United States Coast and Geodetic Survey datum level, but since then others have been used. All precise levelling is now under control of the Geodetic Survey of the Department of the Interior, and an order in council dated March 11, 1935, is quoted in the Canadian Surveyor of January. This order decrees that mean sea-level as determined at coastal points by the Canadian Hydrographic Service shall be the official datum line for elevation in Canada, and shall be known as the Canadian Geodetic Datum.

\section{John Innes Horticultural Institution}

AN informative record of the work of the John Innes Horticultural Institution, Merton, London, S.W.19, from 1910 (the time of its foundation) until 1935, has recently been published. The record opens with a brief survey of the history of the Institution, which was founded by John Innes, a merchant of the City of London. At the beginning, the scope of the work there consisted mainly of genetics, but was later extended to include cytology, biochemistry, mycology, X-ray work and further special investigations. The first director was Dr. W. Bateson, who was succeeded by the present director, Sir Daniel Hall. A very useful list of staff and other workers, who have been at the Institution during the past twenty-five years, is included. Their past and present professional appointments are given. This list is followed by lists of present and past members of the garden staff, and these are followed by a valuable bibliography of publications by the staff, past and present. 